\title{
THE OPPORTUNITIES OF PROFESSIONAL DEVELOPMENT OF OFFICERS
}

\author{
Robert Balcerzyk*
}

\begin{abstract}
Background. A model of the service record of the officers of the Polish Army was presented in this article. The research on the model was conducted in 2015. In 2016, many articles presenting the results of the research on professional competences, training, and vocational training of the officers and their official assessment were published.
\end{abstract}

Research aims. The article is a culmination of the conducted research. The proposed model is partially based on the solutions that already exist, and its innovative character lies in their combination and appropriate direction. The participation of the officers in their own professional development, supplementing knowledge and skills and their verification before subsequent stages of vocational training play a fundamental role in the model. In this model, education in civil organisations (universities) is assumed, if it is required by the specificity of a given position. Moreover, the proposed model (with minor modifications) can be implemented to other Uniformed Public Services.

The goal of this article is to present a model of officers' service record, which was worked out based on research conducted in the years 2012-2015.

Methodology. The following research methods were used in the research presented in this article:

- analysis and criticism of writing (literature within the scope of staff management in the army, analysis of binding legal regulations);

- participant observation method (related to professional experience);

- desk research (research of similar range);

- diagnostic poll with the officers concerning personal subfunction.

Key findings. This model is a solution that can be applied, but it requires changes in the regulations concerning military service of professional soldiers. The consequence of making changes proposed in the model will be raising the level of competences of the officers and confidence of staff in the army and the officers of staff sectors.

Keywords: model of the service record, military service, professional career.

\footnotetext{
* General Tadeusz Kościuszko Military Academy of Land Forces. E-mail: robert.balcerzyk@ awl.edu.pl
} 


\section{INTRODUCTION}

Investing in development of officer corps should synergically coexist with any changes occurring in the Armed Forces of the Republic of Poland, economy and other sectors in order to quickly react to changes. Following the changes in perception of vocational training by officers and soldiers is also important. Therefore, a command's actions should be oriented towards good conditions for development of competences and promotion to higher command positions of officers having experience, skills, and achievements

The goal of this article is to present a model of officers' service record, which was worked out based on research conducted in the years 2012-2015. This article is one of the series on staff management in the Polish Army. The articles preceding this article concerned competences of the officers and their impact on professional career path, raised the issue of the training system and vocational training of the officers, described the problems related to nomination of the officers to official positions, presented determinants of professional careers, particularly barriers, as well as improvements in the system of periodic assessment of the officers. The research and conclusions from it enabled to work out a model of officers' service record (from the rank of second lieutenant to lieutenant-colonel) taking solutions developed in management of human resources in civil organisations into consideration.

The solution (model) proposed in this article is mainly of a developmental and motivating character. It is also a starting point for implementation of real changes in staff practice, within the scope of selecting, assessing, and conducting vocational training of the officers. Without actions aimed at an improvement of the HR function, modern and constantly developing army, will not be able to face up to the challenges of the modern world.

\section{A MODEL OF THE SERVICE RECORD IN THE CONTEXT OF PROFESSIONAL CAREER}

Within the last 20 years, the issue of professional career was in the area of interest of management sciences. There are many monographs and articles concerning career in the works concerning staff management. 
M. Armstrong defines a career as "the ways how people move forward in their work, when they are promoted or broaden or develop their roles to undertake the most important obligations or to make use of their skills and abilities" (Amstrong, 2011, p. 523). Z. Pawlak claimed that a "professional career is a sequence of professions and positions, values and roles fulfilled by the individual. It is shaped in a period preceding professional work and has impact on later period. It is a sequence of subsequent positions of a human considered in terms of professional work" (Pawlak, 2011, p. 370). Career may be connected with promotion or position of an employee in a hierarchical system (power, qualifications, wages). It is usually called a position career, which is related to the hierarchy of wages.

P. Bohdziewicz gives a definition of career as an "individually perceived sequence of attitudes and behaviours resulting from experiences related to work and other activities of a given person" (Bohdziewicz, 2008, p. 36).

A. Miś claimed that career should be considered from four fundamental perspectives (Miś, 2007, p. 24). A career should be considered as a profession. It concerns these professions, in which a specific career path is closely related to accumulation of knowledge and skills required to take up another position. The examples of such professions are teachers and lawyers. Secondly, career may be considered as a professional promotion, that is, taking up positions that are higher in the organisational structure, which gives more decision-making opportunities and more power. Another perspective of career is a sequence of subsequent positions in professional life, that is, individual patterns of subsequent jobs. The last perspective of career is a sequence of experiences of an individual connected with his/her role. Experience shaping internal processes of an individual (aspirations, satisfaction), attitudes towards work due to changing roles play the main role in this perspective.

In order to understand the nature of professional career, specific features of career must be taken into consideration. A. Pocztowski (2007, p. 306) distinguished the following features:

- success or disappointment with reference to professional career depend mainly on the employee, not on other people;

- there are no absolute standards in the assessment of professional career record, the needs of people that they want to satisfy in the sphere of professional activity is a point of reference here;

- professional career is subjective and objective; 
- shaping professional career means making decisions oriented towards achievement of goals of a given employee;

- cultural factors also play a particular role in professional career.

Understanding the nature of career by the employers is an important element in development of any organisation and in full use of the employees' potential. The culture of an organisation and personal practices, which are mutually connected, play an important role (Wyrzykowska \& Karbownik, 2009, pp. 97-99). In these assumptions, change and development are treated as basic conceptual categories. Human capital is characterised by the fact that its particular elements are unique, difficult to follow by the competition, however, their qualitative character makes them hard to measure.

\section{RESEARCH METHODS}

The following research methods were used in the research presented in this article:

- analysis and criticism of writing (literature within the scope of staff management in the army, analysis of binding legal regulations);

- participant observation method (related to professional experience);

- desk research (research of similar range);

- diagnostic poll with the officers concerning personal subfunction.

The triangulations of research methods were applied in order to make the research more reliable. It provided a wider context of the examined phenomenon and higher quality of the conducted research. Using diverse methods gave a coherent empirical base for deduction. The main method in the research work was the diagnostic poll method, whereas other methods were auxiliary (complementary) ones.

A survey questionnaire was worked out on the basis of literature studies, an analysis of legal regulations, and participant observation. The questionnaire was intended for senior and junior officers serving in the Land Forces. Sex, seniority of military service, military rank, and type of recent official position were distinguished in the survey questionnaire.

The main goal of the survey was to collect data concerning the determinants of the professional career of the soldiers (officers). The survey 
questionnaire was divided into three parts. The first part concerned professional competences. The second part of the survey concerned the career of the officers, whereas, the last part of the questionnaire concerned an official assessment. The use of a highly categorised questionnaire enabled placing answers in tabular lists.

\section{CHARACTERISTICS OF THE RESEARCH SAMPLE}

A method proposed by M. Sławińska and H. Witczak was used during selection of the research sample. The officers were divided in terms of their ranks: second lieutenant, lieutenant, captain, major, and lieutenant-colonel. Then, the participation of a given stratum in the whole community was determined. A sample was taken from each stratum, proportionally to participation of a given stratum in the general community. The sample was taken "in a comfortable way". It included:

- junior officers: 265 (including: 65 second lieutenants, 65 lieutenants, and 135 captains);

- $\quad$ senior officers: 86 (including: 53 majors, 26 lieutenant-colonels, and 7 colonels).

- $\quad 351$ officers took part in the research, that is, $5 \%$ of the examined population.

The majority of the population: $75 \%$ - are junior officers (second lieutenants, lieutenants, and captains). The structure of the examined group of the officers in terms of their ranks is presented in Figure 1.

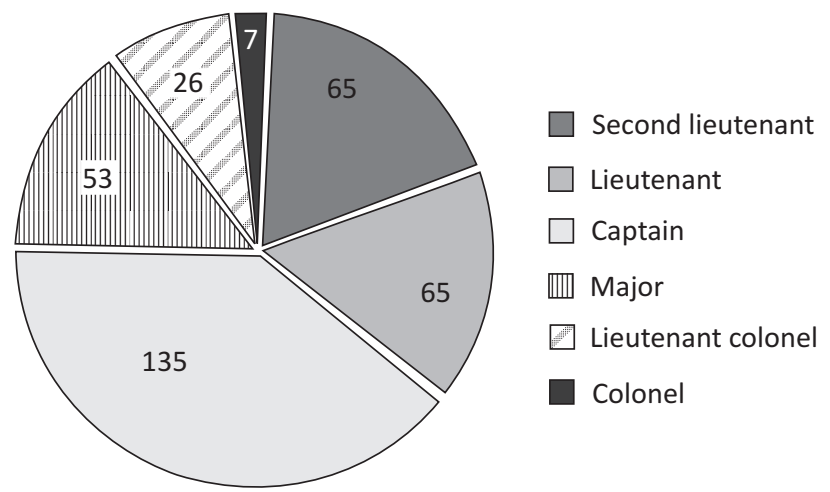

Figure 1. The research sample in terms of their ranks

Source: the author's own research. 
Figure 2 shows data concerning the ratio of women and men in particular ranks. There were no women in the rank of lieutenant-colonel and colonel in the research sample. It is caused by the fact that military service has been available for women only for a dozen or so years, therefore, their professional careers are only in an initial development phase.

The highest percentage of women is among soldiers in the ranks of second lieutenant (18.5\%) and lieutenant (16.9\%). Only a small number of woman were in the rank of major (8.1)\%.

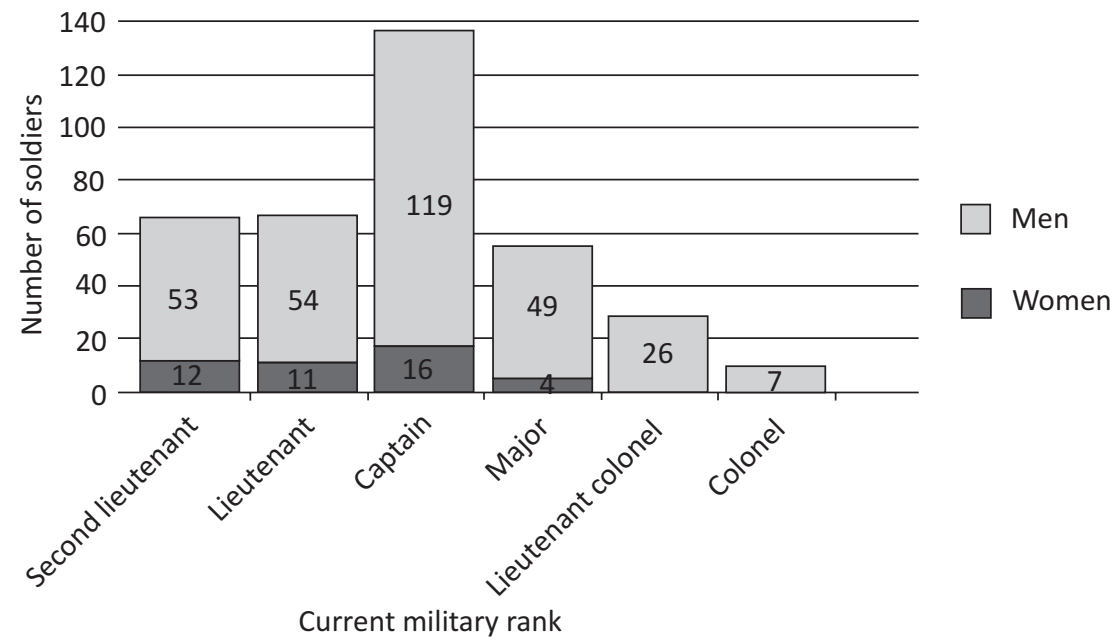

Figure 2. The research sample in terms of their ranks and sex

Source: the author's own research.

Military service seniority of the examined group of the officers is presented in Figure 3.

The majority of the research sample have between 5 and 15 years in their professional military service. It results mainly from the method of sample selection (stratified sampling). More than half of the officers have the rank of lieutenant and captain. The soldiers in these ranks usually have between 7 and 12 years of professional military service. Only 12 soldiers have between 26 and 30 years of professional military service and they are soldiers in the rank of lieutenant-colonel and colonel. It also results from the method of sample selection.

The application of the sample survey enabled collecting data in a relatively short period of time and lowered the costs considerably. 


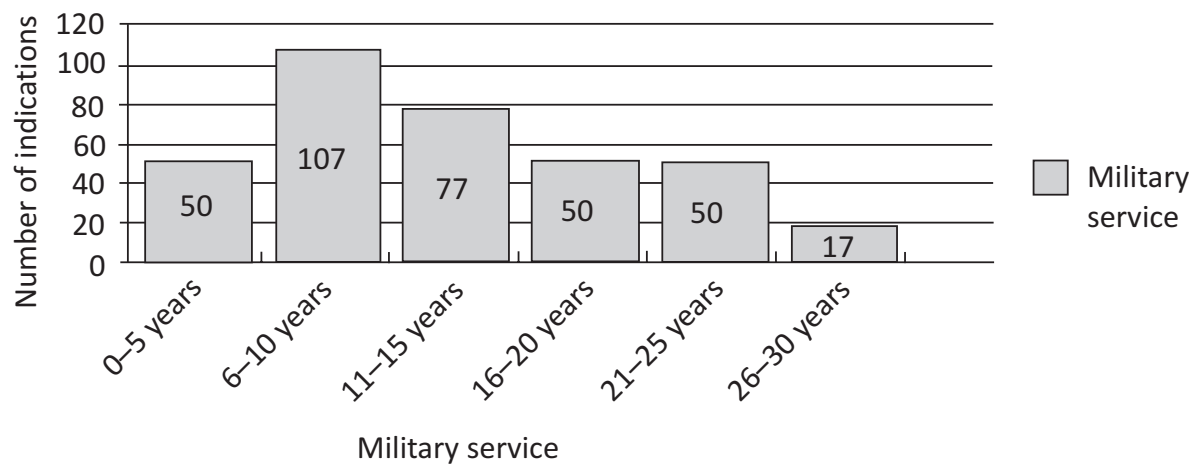

Figure 3. The research sample in terms of seniority

Source: the author's own research.

\section{THE MODEL OF THE PROFESSIONAL CAREER OF THE OFFICERS}

Taking the specificity of the army into consideration, the careers of officers should develop in a predictable way. It will be possible after introduction of two rules: balancing of recruitment with dismissals and professional development in accordance with the developed paths (models) of service record, which should function in a particular corps. The proposed solution will facilitate forecasting of careers and fluctuation of employees will be more predictable.

\section{The assumptions of the model:}

1. The essence of the model is planning the career path of the officers for 35 years of professional military service (the binding pension act assumes that soldiers become eligible for retirement benefits after 25 years of professional military service and when they are 55 years old), ensuring constant development of the officer corps, vocational training and fulfilling the role of a motivator.

2. Promoting officers to subsequent ranks may take place only within a given corps, for example, a soldier assigned to logistics may serve in logistic subunits or positions responsible for logistics. 
3. In the personnel sections, the officers marked out for planning of the officers' careers should be selected (a group of the officers in bigger organisational units).

4. Service at the position should last between 3 and 9 years, and the term 3 years.

5. The idea behind the model is that professional soldiers should know their career path for 3 subsequent terms (9 years).

6. Periodic assessment will be carried out every year by the officer's superior.

7. All professional soldiers who hold a given position at least 12 months will be assessed at the same time.

8. In an assessment sheet, evaluation criteria will be diversified depending on the position.

9. The process of assessment will be supported by specialists psychologists (who work full-time in military units).

10. Periodic assessment will have decisive impact on promotions.

11. Promoting an officer will be possible if he/she will have at least good marks in two recent assessments.

12. A pass mark will not result in dismissal from professional military service, but will make promotion possible.

13. A fail mark will not result in dismissal from professional military service, but in changing the position (within other group of positions).

14. A fail mark (twice in a row) will result in dismissal of an officer from professional military service.

15. A professional soldier will familiarise with the proposed career path and will suggest his/her own expectations towards his/ her career, which should be taken into consideration in the professional career path.

16. Moving the officer to a subsequent position will be possible only after completion of a specialist course, preparing for performance of duties at a new position.

17. The soldiers who, within the last two years, had at least good marks and passed an entrance exam can be sent to a specialist course.

18. The content and subject of the courses should match the expectations of the officers and unit commanders through a comprehensive analysis of the training needs conducted not only by staff bodies, but also by the officers of the training section and department. 
19. The officers performing duties at protective and special positions may participate in courses and studies (postgraduate, doctoral) - at their own expense - organised by civil institutions. It will be taken into consideration while planning the career path.

20. The positions are categorised to two ranks, for example, battalion operational officer; job: second lieutenant/lieutenant, brigade operational officer; job: captain/ major.

21. Promoting to a subsequent rank will be possible without changing the position and will have an impact on:

- assessment results from the two last years;

- professional experience and record of military service;

- conformity of qualifications with the requirements specified in a position description form;

- $\quad$ service seniority in a given rank;

- predispositions to specific positions;

- completion of a specialist course and passing final exams.

22. Promotion will be possible after minimal service seniority in a given rank and promotions to the following ranks will be possible:

- lieutenant - after 4 years of service;

- captain - after 5 years since nomination to the rank of lieutenant;

- major - after 6 years since nomination to the rank of captain;

- lieutenant-colonel - after 6 years since nomination to the rank of major;

- colonel - after 6 years since nomination to the rank of lieutenant-colonel.

The proposed model of service record includes the following minimum requirements for the position in particular groups of positions:

A. For major positions:

- to the position of platoon commander, training section officer of the battalion level (job: second lieutenant/ lieutenant) - having a university degree and completion of a training in military school, initial preparation for the position;

- to the position of company commander/deputy company commander, head of section/training section officer of the 
brigade (job: captain) - military officers' training course (WKDO) in a training centre;

- to the position of battalion commander/deputy battalion commander/ head of section / training section officer of the division (job: major, lieutenant-colonel) - having a master's degree (equal), postgraduate studies at the War Studies University;

- to the position of brigade commander/deputy commander/ head of training of the division/ training department officer of the Command of Land Forces (job: lieutenant-colonel/ colonel) - military strategic and defence course at the War Studies University.

B. For staff positions:

- to the positions of the battalion level (job: second lieutenant/ lieutenant) - having a university degree and completion of a training in a military school, initial preparation for the position;

- $\quad$ to the positions of the brigade level (job: captain) - military officers' training course (WKDO) in a training centre;

- to the positions of the brigade level (job: major) - postgraduate studies at the War Studies University for the officers and heads of reconnaissance and operational sections, postgraduate studies in civil schools for the officers and heads of personnel and logistics section;

- to the positions of the division level (job: major/ lieutenant-colonel) - postgraduate studies at the War Studies University for the officers and heads of reconnaissance and operational sections, postgraduate studies in civil schools for the officers and heads of the personnel and logistics section;

- to the positions of the level of the Command of Land Forces (colonel) - military strategic and defence course at the War Studies University, for the officers and heads of the personnel and logistics section, having an academic degree of Doctor.

Contemporary commands of units, institutions, or military schools are the "technological line", and their final effect should be preparation of commanding, staff, and specialist corps for effective commanding of military units in peacetime or crisis situation, but also in wartime. The proposed model should be implemented in peacetime. In this 
model, the positions are divided into fundamental, protective, and special positions.

The group of fundamental positions consists of command and training positions. The officers nominated to the positions within this group must have unique predispositions and skills. The tasks carried out by the officers serving at these positions will be changing, depending on the command level and capabilities of particular military units. The officers should have leadership skills.

The second group of positions will be protective positions, including staff and logistic positions. Nomination of an officer to the first protective position will depend on performance of duties at the first fundamental position - platoon commander. The specialists and experts should take up these positions. These officers should become proficient and independent in performing their duties.

The third group are special positions, the only difference is that soldiers are not verified in terms of command predispositions. For the first position, they will be nominated within special positions. Nomination of a professional officer to a special position depends on his/her special qualifications or fulfilment of requirements for certain professions. Nomination of an officer to a special position will depend on the available positions and experience at a given position, as well as good or very good marks in periodic assessments. A professional soldier serving at a special position cannot be nominated to major or protective positions.

During modelling, we should remember that protective or special positions may not be treated as jobs for second class soldiers, whose marks in the assessment are " 3 " (sufficient) or " 2 " (fail). These jobs should be regarded as an element of stabilisation of the Armed Forces. The soldiers who "do not fit" in a very limited area of fundamental positions should take up these positions. It should be treated as a natural effect of the limited number of fundamental positions and actions aimed at the stabilisation of army structures.

All officers will have equal opportunities. The second lieutenants will start from the rank of platoon commander (except for special positions). After the first year of service, the qualification procedure will be conducted by a verification committee. Young officers will undergo competency assessment tests. These tests will check theoretical knowledge and practical performance of the tasks by the platoon. Moreover, the second lieutenants will undergo psychological tests determining 


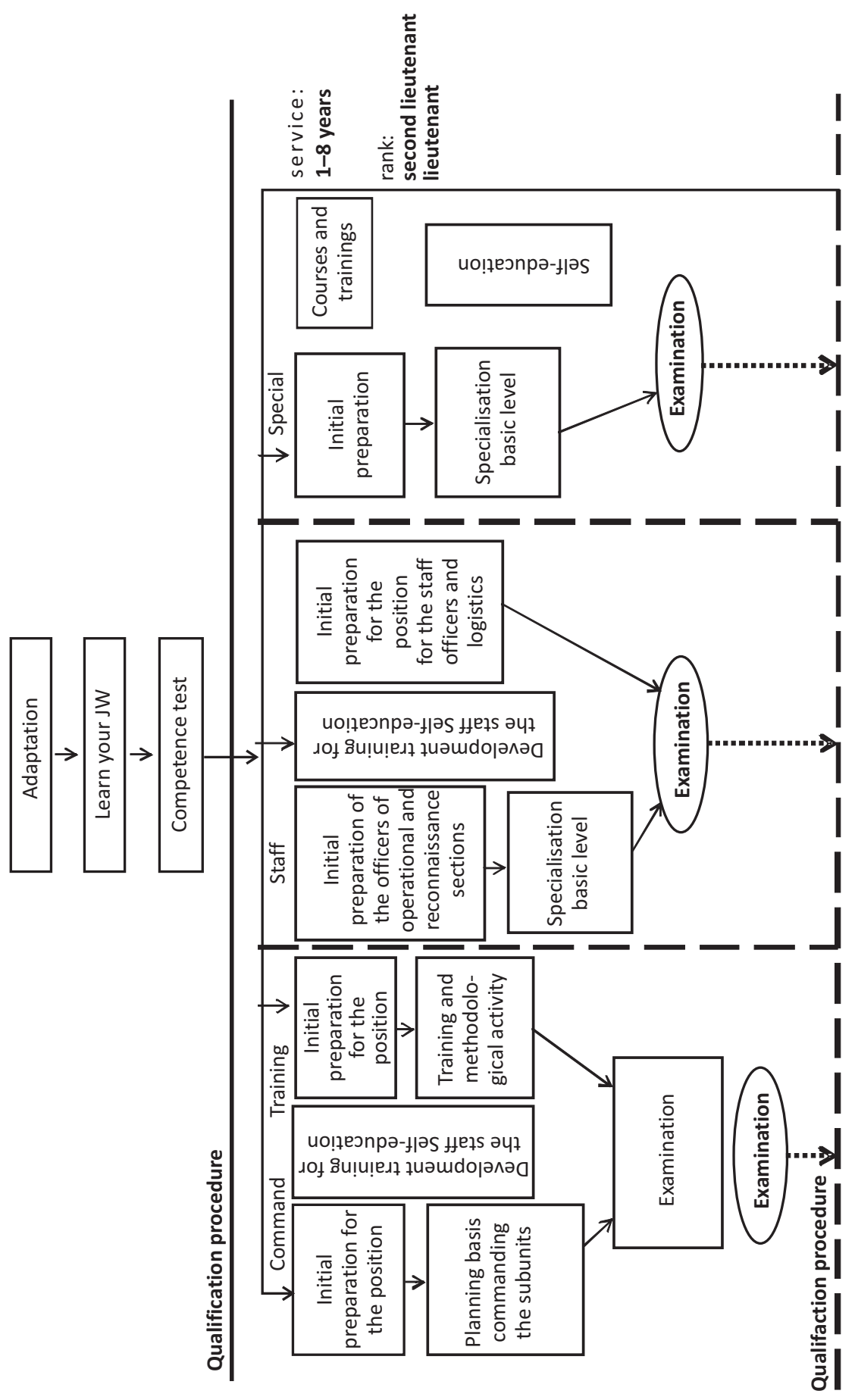




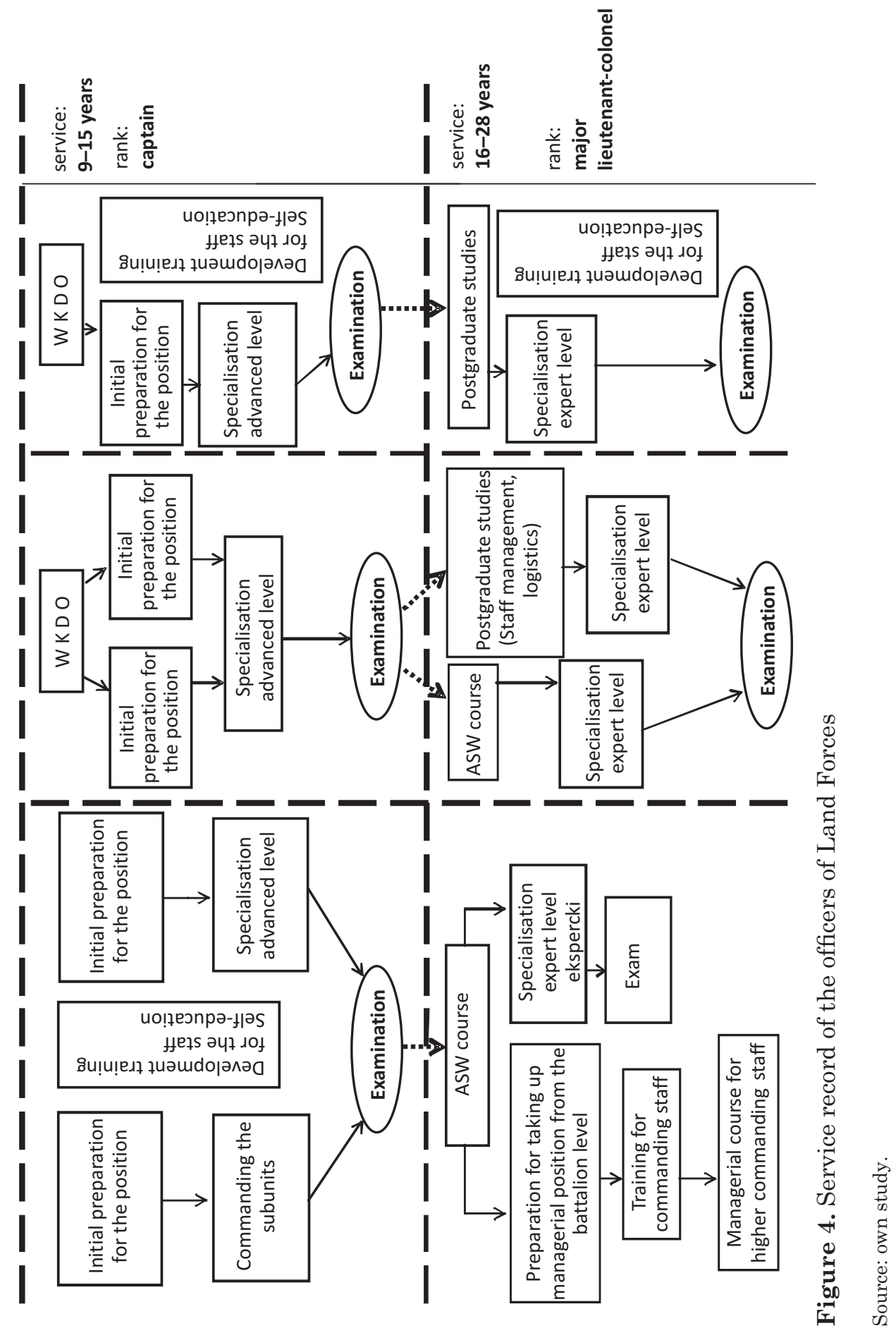


his/her personality traits and predispositions to be a leader. These tests will be conducted by specialised units - psychological units (which have already been established). A periodic assessment made by a superior will be taken into consideration. In case of any doubts regarding an officer's usefulness to fundamental positions, the periodic assessment made by a superior will be the decisive factor. An officer will be assigned to one of two groups of positions as a result of the qualification procedure.

After verification of usefulness of the officers to particular groups of positions, the first positions will be positions at the battalion level. Before taking up the official positions, the officers will have to participate in initial preparation for the position, ending up with an examination. The competences will be acquired during performance of official duties, training for the staff, and self-education.

After about 8 years of service, they will be able to take up positions at the level of brigade. In order to take up a position in the brigade, they will be sent to a military officers' training course, preceded by entrance examinations. After passing the exams, they will be nominated to the positions in the brigade. For the whole duration of service, the soldier may be promoted in accordance with the assumptions of the model.

After 16 years of professional military service, they would have to serve in organisational sections of the division. Before taking up the positions, the officers and heads of reconnaissance and operational sections will have to complete postgraduate studies at the War Studies University, and officers and heads of the personnel and logistics section will have to complete postgraduate studies in civil schools. Such education will enable them to be promoted to the rank of lieutenant-colonel. Only officers from a group of command positions, before nomination to the position of deputy battalion commander will also have to complete postgraduate studies at the War Studies University.

After 25 years of professional military service, the officers will be able to serve in the Command of Land Forces. The condition will be completion of a military strategic and defence course at the War Studies University for the officers of operational and reconnaissance sections, whereas, for the officers and heads of the personnel and logistics section, having the academic degree of Doctor. The exception are officers from a group of command positions, who, before nomination to the position of deputy brigade commander, will have to complete a military strategic and defence course at the War Studies University. 
The officers from a group of special positions after initial preparation for the position would serve at the positions in the brigade. Through participation in civil training and courses and self-education, they would enrich their individual career capital. After about 15 years of service, they would serve in the division. The condition is completion of postgraduate studies (civil) and military officers' training course (WKDO) in a training centre preceded by entrance examinations. After 10 years of service in the organisational units of the division, they could take up positions in the Command of Land Forces after completion of an officers' training course (WKDO) in a training centre and having the academic degree of Doctor.

The idea behind this model is that before commencement of each qualification course conducted in military training centres or postgraduate studies at the War Studies University, the candidates will have to pass entrance examinations verifying the level of knowledge and skills. After completion of training or studies, an officer would have to pass final examinations verifying his/her knowledge and skills. In this way, the Armed Forces will have qualified staff with high competences.

The rule says that before every nomination to the position, an officer must pass a competence test. This test should include:

- tests concerning knowledge necessary in a given position;

- checking required qualifications with requirements specified in a position description form;

- professional experience and current career path (performance of official duties in a specific group of positions);

- service seniority in a given rank;

- periodic assessment (two last marks);

- having appropriate predispositions to a specific position.

It is important to verify leadership skills of an officer one year after completion of a military academy during performance of duties at the position of platoon commander. The career path of a soldier should be determined individually. The soldiers having leadership skills should be nominated to the command positions and training section, the others to staff, logistic, administrative, or educational positions. Selecting soldiers having specific competences should be a significant element of the HR policy and closely related to the staff development system.

Based on the conducted research, it may be concluded that contemporary professional careers of soldiers are not based on selection of 
officers with a wide experience and degrees, but on young people with adaptive skills who have appropriate relational capital.

People having specific competences should be nominated as staff officers. People who have, for example, civil education in the field of management of human resources, know the specificity of personal service and modern trends in management of people.

The staff officers and superiors do not obey the basic rule in management of human resources (which was shown in the research) that guarantees the success of an organisation, that is, the goals of an individual and goals of the organisation should be coherent. Aspirations and professional plans should be taken into consideration while planning careers. They should also meet the expectations of staff bodies resulting from planning careers. However, it is not easy because 2/3 of the respondents do not know their career path.

The current system of human resources management does not have a motivational function and does not make use of the willingness of the officers to self-education.

The above research may also serve as an argument to make changes in the system of management of officers' career and system of nomination of officers to the positions. These changes are needed in the policy of the HR department of National Defence due to professionalisation of the Army and pending restructuring of the Armed Forces of the Republic of Poland.

\section{SUMMARY}

Every organisation takes actions in order to improve the procedures and standards of promoting employees. The modern military career, lasting 30 years in one military unit or garrison is a thing of the past. The current pace of changes and restructuring of the Armed Forces make determination of the career goal more and more difficult. However, if the intention of the Polish Army is to achieve successes during missions, it must develop competences of soldiers, particularly officer corps. The system of career management must be modified to achieve this goal. Quick promotion of people to realise their own interests should be rejected. It is also important to reject the assumption that a person who is highly qualified in a given speciality also has well-developed leadership skills. 
Investing in the development of the officer corps should synergically coexist with any changes occurring in the Armed Forces of the Republic of Poland, the economy, and other sectors in order to quickly react to changes. Following the changes in the perception of career by officers and soldiers is also important. Therefore, a command's actions should be oriented towards good conditions for development of competences and promotion to higher command positions of officers having experience, skills, and achievements.

The second goal of this article was to work out a model of service record of the officers of the Land Forces in the context of modern solutions of management of human resources in the organisations. This model is based on the assumptions of a model of human capital, where competences play a fundamental role. Its important feature is universality, that is, the possibility of implementation of this model to other uniformed services (police, border guard). Moreover, the proposed model is partially based on solutions that already exist, and its innovative character lies in their combination and appropriate direction. The participation of officers in their own professional development, supplementing knowledge and skills and their verification before subsequent stages of vocational training play a fundamental role in the model. In this model, education in civil organisations (universities) is assumed, if it is required by the specificity of a given position. Its advantage is also a low cost of implementation. This model is a solution that can be applied, but it requires changes in regulations concerning military service of professional soldiers. The consequences of changes proposed in the model will be raising the level of competences of officers and confidence of staff in the army and officers of staff sectors.

\section{REFERENCES}

Amstrong, M. (2011). Zarzadzanie zasobami ludzkimi. Strategia i działanie. Kraków: Wydawnictwo Profesjonalnej Szkoły Biznesu.

Antczak, Z. (2010). Rozwój pracowników. In: T. Listwan (ed.), Zarzqdzanie kadrami. Warszawa: Wydawnictwo C.H. Beck.

Antczak, Z. (2006). Menedżer na przełomie XX i XXI w. funkcjonujący w organizacjach na terenie Polski. In: T. Listwan \& S.A. Witkowski (eds.), Menedżer $w$ gospodarce opartej na wiedzy. Warszawa: Wydawnictwo C.H. Beck. 
Bohdziewicz, P. (2008). Kariery zawodowe. Łódź: Wydawnictwo Uniwersytetu Łódzkiego.

Drucker P. (2011). Praktyka zarzadzania. Warszawa: Wydawnictwo MT Biznes.

Filipowicz, G. (2004). Zarzadzanie kompetencjami zawodowymi. Warszawa: PWE.

Król, H. \& Ludwiczyński, A. (2014). Zarzadzanie zasobami ludzkimi. Warszawa: Wydawnictwo Naukowe PWN.

Miś, A. (2007). Koncepcja rozwoju kariery zawodowej w organizacji. Kraków: Uniwersytet Ekonomiczny.

Moczydłowska, J. (2008). Zarzadzanie kompetencjami zawodowymi a motywowanie pracowników. Warszawa: Wydawnictwo Centrum Doradztwa i Informacji Difin.

Pawlak, Z. (2011). Zarzadzanie zasobami ludzkimi w przedsiębiorstwie. Warszawa: Poltext.

Pocztowski, A. (2007). Zarzadzanie zasobami ludzkimi. Warszawa: PWE.

Rostkowski, T. (2004). Kompetencje a jakość zarządzania zasobami ludzkimi. In: A. Sajkiewicz (ed.), Jakość zasobów pracy. Kultura, kompetencje, konkurencyjność. Warszawa: Poltext.

Sudoł, S. (2011). Kadra kierownicza w przedsiębiorstwie. In: B. Godziszewski, M. Haffer, M.J. Stankiewicz \& S. Sudoł (eds.), Przedsiębiorstwo. Warszawa: PWE.

Sutherland, J. \& Canwell, D. (2007). Klucz do zarzadzania zasobami ludzkiminajważniejsze teorie, pojęcia, postacie. Warszawa: Wydawnictwo Naukowe PWN.

Wieczorek, J. (2008). Efektywne zarzadzanie kompetencjami. Tworzenie przewagi konkurencyjnej firmy. Gdańsk: Ośrodek Doradztwa i Doskonalenia Kadr.

Woodruffe, Ch. (2003). Ośrodki oceny i rozwoju. Narzędzia analizy i doskonalenia kompetencji pracowników. Kraków: Oficyna Ekonomiczna.

Wyrzykowska, B. \& Karbownik, K. (2009). Kierowanie zasobami ludzkimi w organizacji. Warszawa: Wydawnictwo SGGW. 


\title{
MOŻLIWOŚCI ROZWOJU ZAWODOWEGO OFICERÓW
}

\begin{abstract}
Abstrakt
Tło badań. W artykule zaprezentowano model przebiegu służby oficerów Wojska Polskiego. Badania dotyczące modelu zostały zakończone w 2015 roku. W roku 2016 zostało opublikowanych szereg artykułów prezentujących obszerne wyniki badań dotyczace kompetencji zawodowych, szkolenia i doskonalenia zawodowego oficerów oraz ich opiniowania służbowego.
\end{abstract}

Cel badań. Prezentowany artykuł jest zwieńczeniem prowadzonych prac badawczych. Zaproponowany model bazuje częściowo na już funkcjonujących rozwiązaniach, a jego nowatorstwo polega na ich połączeniu i odpowiednim ukierunkowaniu. W modelu zasadniczą rolę odgrywa partycypacja oficerów we własnym rozwoju zawodowym, uzupełnianie niedoborów wiedzy i umiejętności oraz ich weryfikacja przed kolejnymi etapami doskonalenia zawodowego. W modelu tym zakłada się dokształcanie w organizacjach cywilnych (m.in. uczelniach wyższych), jeżeli wymaga tego specyfika stanowiska służbowego. Ponadto proponowany model (po drobnych modyfikacjach) można wdrożyć do innych grup dyspozycyjnych.

Metodologia. W badaniach prezentowanych w artykule wykorzystano następujace metody:

- metodę analizy i krytyki piśmiennictwa (literatura w zakresie zarządzania kadrami w wojsku, analiza obowiązujących aktów prawnych);

- metodę obserwacji uczestniczącej (związaną z doświadczeniem zawodowym);

- analizę źródeł wtórnych (badania o podobnym zakresie);

- sondaż diagnostyczny z oficerami dotyczący subfunkcji personalnej.

Kluczowe wnioski. Model ten jest rozwiązaniem możliwym do zastosowania, ale wymagajaccym zmian w przepisach dotyczących służby wojskowej żołnierzy zawodowych. Konsekwencja wprowadzenia zmian zaproponowanych w modelu będzie podniesienie poziomu kompetencji oficerów oraz zwiększenie zaufania kadry do organizacji, jaka jest wojsko, oraz do oficerów pionów kadrowych.

Słowa kluczowe: model przebiegu służby, służba wojskowa, kariera zawodowa. 